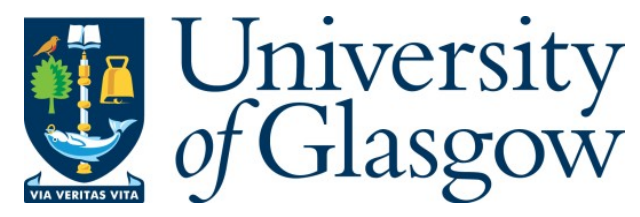

Bowie, K. (2013) Cultural, British and global turns in the history of Early Modern Scotland. Scottish Historical Review, 92 (234). pp. 38-48. ISSN 0036-9241

Copyright (C) 2013 Scottish Historical Review Trust

A copy can be downloaded for personal non-commercial research or study, without prior permission or charge

Content must not be changed in any way or reproduced in any format or medium without the formal permission of the copyright holder(s)

When referring to this work, full bibliographic details must be given

$\underline{\text { http://eprints.gla.ac.uk/84176 }}$

Deposited on: 08 August 2013

Enlighten - Research publications by members of the University of Glasgow http://eprints.gla.ac.uk 


\section{Cultural, British and Global Turns in the History of Early Modern Scotland}

In 1994, as part of a stock-taking instigated by the SHR Trust, four historians offered a broadly positive assessment of the historiography of early modern Scotland. Focusing on the seventeenth and eighteenth centuries, their papers highlighted a shift away from insular narratives and narrow Anglo-Scottish comparisons towards a wider contextualisation of Scottish history. Concurrent with this shift, it was argued, the professional standards and output of the field had risen. The field was moving with the times but, as one scholar stressed, resisting the alien forces of postmodernism. ${ }^{1}$

Nearly two decades later, though few Scottish historians would label themselves postmodernists, postmodern and poststructural influences have diffused into Scottish history through the 'cultural turn', altering the terms of debate in a number of traditional topics in early modern historiography. At the same time, present-day concerns, from postcolonialism to devolution, have combined with ongoing empirical revisionism and the cultural turn to reshape the history of Britain and its empire, again with significant implications for early modern Scottish history. Most recently, the rise of interest in globalisation and its history has expanded the international contexts in which Scottish history can be situated. Alongside these intellectual shifts, key sources have become more available to scholars and students alike through the exploitation of new funding streams and technologies. This paper will consider the impact of these trends on histories of Scotland in the seventeenth and eighteenth centuries. $^{2}$

1 A.I. Macinnes, 'Early modern Scotland: the current state of play', Michael Lynch, 'Response: Old Games and New', R.A. Houston, 'Eighteenth-century Scottish studies: out of the laager?' and C.A. Whatley, 'Response: flat laager?', SHR 73 (1994) 31-88. Macinnes expressed resistance to postmodernism with the memorable phrase, 'Foucault off!' (p. 46).

2 This paper includes points raised by the audience at the SHR Trust's conference on the state of Scottish history (29 October 2010), for which I am grateful. I would like to thank Keith Brown for his invitation to join the early modern panel and Keith, Colin Kidd, Laura Stewart, Andrew Mackillop and Amanda Epperson for their helpful comments on this paper.

KARIN BOWIE is a Lecturer in History in the School of Humanities at the University of Glasgow. 
Scottish history has had a strong tradition of source publication through antiquarian and scholarly societies, from the Bannatyne Club to the Scottish History Society. In the 1994 review, it was noted that historical computing offered new opportunities by enabling large-scale database analysis. ${ }^{3}$ Since then, this technological opening has been exploited by academics using grants to assemble teams to transcribe, digitise and assess vast quantities of manuscript sources. Though such projects challenge the historical profession's traditionally individualistic ways of working, database team projects have produced substantive benefits for early modern Scottish history.

Perhaps the most noteworthy project has been the Scottish Parliament Project, which was funded by the devolved Scottish government to place on a searchable database the records of the Scottish parliament to 1707 . The team has produced an accompanying threevolume history of the Scottish parliament. ${ }^{4}$ This work has offered fundamental challenges to earlier interpretations of the political role of Parliament, while making it much easier to research and teach parliamentary and political history. Another significant project has been the Survey of Scottish Witchcraft. This database offers a comprehensive directory of all known witchcraft cases supported by a detailed search function. Members of the project have published two edited collections on Scottish witchcraft, as well as individual articles. This has fleshed out what had been a skeletal field in Scotland while making notable contributions to the wider field at an international level. ${ }^{5}$ Moreover, both projects have helped to sustain the discipline in Scotland by funding doctoral and postdoctoral positions for new scholars.

\section{II}

While grant-funded technology has created new outputs and ways of working, the most significant recent influence on approaches to Scottish history has been the 'cultural turn'. Across the discipline, the 'cultural turn' can be seen in a move away from social, economic and institutional histories towards histories of cultural practices and beliefs, embedded in social settings. ${ }^{6}$ For most historians, 'culture' now means something more than the art and literature of an educated elite. For many scholars,

3 Macinnes, 'Early modern Scotland', 45.

4 Records of the Parliaments of Scotland to 1707, http://www.rps.ac.uk/; K. Brown (ed.), History of the Scottish Parliament, 3 vols. (Edinburgh, 2004-2010).

5 The Survey of Scottish Witchcraft, 1563-1736, http://www.shc.ed.ac.uk/Research/witches/. J. Goodare, L. Martin and J. Miller (eds), Witchcraft and Belief in Early Modern Scotland (Basingstoke, 2008); J. Goodare (ed.), The Scottish Witch-Hunt in Context (Manchester, 2002).

6 For more on the cultural turn, see L. Hunt (ed.), The New Cultural History (Berkeley, CA, 1989); P. Burke, A Social History of Knowledge: from Gutenberg to Diderot (Cambridge, 2000), 1-17. One sign of the impact of the cultural turn on Scottish history was the 2005 name change of the Scottish Economic and Social History journal to the Journal of Scottish Historical Studies. The decline in traditional economic and 
the cultural turn has redefined objects of study as manifestations of culture rather than structures or institutions. Traditional topics have been transformed as historians study piety instead of the church, consumption instead of class and political culture instead of politics. ${ }^{7}$

Church history, long a defining category of Scottish historical research, has taken a cultural turn towards the history of religious belief and practice. Perhaps the most notable work reflecting this shift was Margo Todd's 2002 study, The Culture of Protestantism in Early Modern Scotland. Rejecting a traditional focus on 'the Kirk' and top-down measures of Reformation, Todd applied an explicitly anthropological method to the evidence of kirk session minutes to produce a nuanced study of the means by which Scotland's religious culture was Protestantised at the parish level in the decades after 1560 . Though her study stops at the National Covenant, it has implications for subsequent decades. In showing how a coherent Protestant culture was created in much of Scotland by the early seventeenth century, Todd's work provides a cultural context for the religious politics of the ensuing century and beyond. ${ }^{8}$ It also suggests the usefulness of the notion of a 'long Reformation' in Scotland to encompass competing versions of Protestantism and their relationship to political parties and events. Though Todd sees Scotland as a 'puritan nation' by the $1630 \mathrm{~s}$, this godly consensus contained tensions on issues of church government and worship that would feed into the later development of Presbyterian and Episcopalian confessional cultures. ${ }^{9}$ For some time, continental and English historians have made use of the notion of the 'long Reformation' to capture ongoing processes of change and accommodation between and within Protestantism and Catholicism. ${ }^{10}$ Recent work on the clash between orthodox and moderate Calvinism in Enlightenment Scotland shows how the idea of a 'long Reformation' can place Scottish cultural politics both in a deep chronological and a broad historiographical framework. ${ }^{11}$

This deep chronology indicates the expanding boundaries of 'early modern' Scottish history. In the present assessment, this and

6 (Continued) social history was investigated in a symposium, 'The strange death of economic and social history?', Economic and Social History Society of Scotland, Glasgow Caledonian University, 20 December 2008.

7 K. Barclay and S. Talbott also stress the cultural turn in their New perspectives on seventeenth and eighteenth century Scotland: the Economic and Social History Society of Scotland Conference 2010', Journal of Scottish Historical Studies 31(2011) 119-133.

8 Todd's approach has been supplemented with regional studies, e.g. J. McCallum, Reforming the Scottish Parish: the Reformation in Fife, 1560-1640 (Farnham, 2010), and investigations of evangelical piety, e.g. D. G. Mullan, Narratives of the Religious Self in Early-Modern Scotland (Farnham, 2010).

9 A. Raffe, 'Presbyterians and Episcopalians: the Formation of Confessional Cultures in Scotland, 1660-1715', English Historical Review 125 (June 2010) 570-598.

10 For example, N. Tyacke (ed.), England's Long Reformation, 1550-1800 (London, 1998).

11 L. Brekke, 'Heretics in the Pulpit, Inquisitors in the Pews: The Long Reformation and the Scottish Enlightenment', Eighteenth-Century Studies 44 (2010) 79-98. 
Laura Stewart's paper together discuss themes extending from the sixteenth to the eighteenth century. In contrast, as late as the 1970s, leading historians like Hugh Trevor-Roper stressed the medieval nature of Scotland before 1707. ${ }^{12}$ This perspective reflected a traditional institutional approach to history that saw the Union of 1707 as a fundamental turning point. A cultural approach, however, has encouraged a more generous view of the early modern era in Scotland by examining change across political boundaries and milestones. As a result, for many historians the early modern period has transformed from a post-1707 sprint to a much longer and more complex period of change. ${ }^{13}$

Within the early modern period, the cultural turn has reshaped one of Scottish history's biggest topics, the making of the Union of 1707. By paying attention to religious and political culture, scholars have reconfigured what had become, by the 1980s, a reductive tug of war between political and economic explanations for union. New work has sketched out spectrums of Presbyterian and Episcopalian commitments, Williamite and Jacobite political loyalties and federal and incorporating unionisms, expanding our appreciation of the rich diversity of contemporary opinion. ${ }^{14}$ As well, narrowly Namierite conceptions of Scottish political practices have been challenged with new work on the significance of popular protest and parliamentary debate.$^{15}$ With the help of fresh research on the book trade in Scotland, the proliferation of pamphleteering in the decade before the union can be understood as more than just froth on dark political waters. ${ }^{16}$ Close analysis of pamphlets by intellectual historians sensitive to Scotland's cultural context has given new credence to the political thought of the time. ${ }^{17}$ As a consequence, a cultural interpretation, focusing on the significance of Protestant loyalties in a post-1688 geopolitical context, now dominates tercentennial views of the Union. ${ }^{18}$

The prominence of the Jacobite threat in new narratives of the Union points to a parallel renaissance in Jacobite studies. Research on

12 H. Trevor-Roper, 'The Anglo-Scottish Union', in From Counter-Reformation to Glorious Revolution, (London: Secker \& Warburg, 1992). (First published in 1977.)

13 K. Bowie, 'Re-assessing Pre-Union Scotland' in T.M. Devine and J. Wormald (eds), The Oxford Handbook of Modern Scottish History (Oxford, 2012).

14 C. Kidd, 'Religious realignment between the Revolution and the Union' in J. Robertson (ed.), A Union for Empire: Political Thought and the Union of 1707 (Cambridge, 1995) and Union and Unionisms: Political Thought in Scotland, 1500-2000 (Cambridge, 2008); K. Bowie, 'Popular resistance, Religion and the Union of 1707' in T. M. Devine (ed.), Scotland and the Union 1707-2007 (Edinburgh, 2008).

15 K. Bowie, Scottish Public Opinion and the Anglo-Scottish Union, 1699-1707 (Woodbridge, 2007); C. Whately with D. Patrick, The Scots and the Union (Edinburgh, 2006).

16 A. J. Mann, The Scottish Book Trade 1500-1720 (East Lothian, 2000).

17 J. Robertson, 'An Elusive Sovereignty: The Course of the Union Debate in Scotland 1698-1707' in Robertson (ed.), Union for Empire.

18 B. Harris, 'The Anglo-Scottish Treaty of Union, 1707 in 2007: Defending the Revolution, Defeating the Jacobites', Journal of British Studies 49 (January 2010) 28-46. 
Jacobitism, once considered the purview of conservatives and cranks, has become an arena for cutting edge cultural analysis. With the deconstruction of Whig accounts of modernity that saw Jacobitism as the doomed ideology of the unprogressive, the cultural turn has encouraged study of the beliefs and practices of Stuart royalism and its associated Episcopalian piety. ${ }^{19}$ In light of this, Jacobitism has emerged as more than the atavistic hopes of backwards clan chiefs. ${ }^{20}$ A cultural approach has helped to explain the tenacity of Jacobitism in difficult political circumstances by demonstrating its deep cultural roots in neoLatin humanism and, at the same time, its congruity with Gaelic cultural beliefs. ${ }^{21}$ Regional studies have begun to reconstruct a living culture at the grassroots, with attention to popular as well as elite loyalty to the Stuart dynasty. This work has challenged traditional definitions of the Jacobites as Highland Catholic elites and demonstrated the Presbyterian-Episcopalian tensions present within many early modern Scottish communities. ${ }^{22}$

As in work on the (long) Reformation, the Union and Jacobitism, the cultural turn has reoriented studies of the Enlightenment in Scotland. In recent decades, historians of the Enlightenment have turned their attention from a privileged canon of authors and arguments to the cultural and social contexts of writers and readers. This has encouraged new research on the evolution of the Enlightenment in Scotland and the diffusion of Enlightenment ideas inside and outside Scotland. Scholars have stressed the national context of the Enlightenment in Scotland by identifying the social, institutional and cultural conditions in which authors and their patrons operated. ${ }^{23}$ As in the early modern period more generally, the boundaries of the Scottish Enlightenment have expanded. The origins of the Enlightenment in Scotland have been explored deep into the seventeenth century and beyond, driven by a long-running debate on the extent to which the 1707 Union made the Enlightenment possible in Scotland.$^{24}$ Scholars have asked how Scottish Enlightenment thought made its way to other cultural and social

19 J. C. D. Clark, 'The many restorations of King James: a short history of scholarship on Jacobitism, 1688-2006' in P. Monod, M. Pittock and D. Szechi (eds), Loyalty and Identity: Jacobites at Home and Abroad (Houndmills, 2010); C. Jackson, Restoration Scotland, 1660-1690: Royalist Politics, Religion and Ideas (Woodbridge, 2003).

20 D. Szechi, 1715: the Great Jacobite Rebellion (London and New Haven, 2006).

21 D. Allan, Philosophy and Politics in Later Stuart Scotland: Neo-Stoicism, Culture and Ideology in an Age of Crisis, 1540-1690 (East Linton, 2000); A. I. Macinnes, Clanship, Commerce and the House of Stewart, 1603-1788 (East Linton, 1996).

22 M. Pittock, The Myth of the Jacobite Clans (Edinburgh, 1995, 2009); T. N. Clarke, "Nurseries of sedition"?: the Episcopal Congregations after the Revolution of 1689' in J. Porter (ed.), After Columba, after Calvin: Community and Identity in the Religious Traditions of North East Scotland, (Aberdeen, 1999); K. German, 'Jacobite politics in Aberdeen and the '15' in Monod et al, Loyalty and Identity.

23 R. Sher, Church and University in the Scottish Enlightenment: the Moderate Literati of Edinburgh (Edinburgh, 1985).

24 A sample includes H. Ouston, 'York in Edinburgh: James VII and the patronage of learning in Scotland, 1679-1688' in J. Dwyer, R. A. Mason and A. Murdoch (eds), New Perspectives on the Politics and Culture of Early Modern Scotland (Edinburgh, 1982); 
contexts through the publishing of Scottish authors in Anglophone markets; and have explored the extent to which ordinary Scots engaged with, accepted or rejected Enlightenment thinking. ${ }^{25}$ At the same time, the Scottish case has been used to support an argument for a return to a more restricted definition of 'the Enlightenment' as a particular set of thoughts articulated in a limited timeframe. ${ }^{26}$ A more cultural approach to the Enlightenment in Scotland thus has contributed to vigorous debates in the wider field of Enlightenment studies while improving our understanding of early modern Scottish culture and society.

Two fields noted as emerging in 1994, women's history and popular culture, have continued to expand on lines influenced by the cultural turn. Since 1994, women's history has followed the cultural turn towards gender studies. This field has been slow to develop in a Scottish context, but recent work has explored the gendering of social practices, notably in studies of piety, crime and social control. ${ }^{27}$ In popular culture, the cultural turn can be seen in a growing poststructuralist distrust of simple dichotomies between popular and elite. This has led a recent project to adopt the framework of 'everyday life', in which the history of smells appears alongside more traditional topics of work, housing and lifestages. ${ }^{28}$ Another mode of study is the history of the family, where work on godly families helps to explain the survival of Covenanting culture after the Restoration. ${ }^{29}$ In the realm of popular belief, work on witchcraft, noted above, has been accompanied by new research on postReformation Scottish beliefs in magic and the supernatural. ${ }^{30}$ Cultural analysis of riots and protests has been used to challenge long-held ideas

(Continued) R. Emerson, 'Sir Robert Sibbald, Kt, the Royal Society of Scotland and the origins of the Scottish Enlightenment', Annals of Science 45 (1988), 41-72; M. Graham, The Blasphemies of Thomas Aikenhead: Boundaries of Belief on the Eve of the Enlightenment (Edinburgh, 2008).

25 R. Sher, The Enlightenment and the Book: Scottish Authors and their Publishers in EighteenthCentury Britain, Ireland and America (Chicago and London, 2006); S. Nenadic, 'The Enlightenment in Scotland and the popular passion for portraits', British Journal for Eighteenth-Century Studies 21 (1998) 175-192; M. Towsey, "Patron of infidelity": Scottish readers respond to David Hume, c.1750-c.1820', Book History 11 (2008) 89-123 and Reading the Scottish Enlightenment: Books and their Readers in Provincial Scotland, 1750-1820 (Leiden, 2010).

26 J. Robertson, The Case for the Enlightenment: Scotland and Naples 1680-1760 (Cambridge, 2005).

27 For a recent overview, see E. Ewan, 'A new trumpet? The history of women in Scotland 1300-1700’, History Compass 7 (2009) 431-446. See also the article on gender history in this volume.

28 E. Foyster and C. A. Whatley (eds), A History of Everyday Life: Scotland, 1600-1800 (Edinburgh, 2010). For a more traditional ethnographic approach to popular culture, see Scottish Life and Society: a Compendium of Scottish Ethnology, 14 vols. (Edinburgh, 2000-2009).

29 E. Ewan and J. Nugent (eds), Finding the Family in Medieval and Early Modern Scotland (Aldershot, 2008); Mullan, Narratives of the Religious Self.

30 E. J. Cowan and L. Henderson, Scottish Fairy Belief (East Linton, 2001). 
about Scottish society, in particular the view that early modern Scots were subjected to the tyranny of church and nobles. ${ }^{31}$

Though this paper highlights the fresh insights provided by the cultural turn in a range of traditional topics, a note of caution should be sounded. A concomitant decline in structuralism, Marxist or macroeconomic, has made discussion of class and socio-economic change less fashionable. In current work, groups are more likely to be defined by cultural practices, for example by a typology of piety or consumer behaviour, than by socio-economic status or relationships to modes of production. In social history, for example, research now seeks to identify the middling rank through their participation in the burgeoning consumer culture of eighteenth-century Scotland. ${ }^{32}$ Cultural scholars tend to highlight vertical connections across social levels and avoid blanket attribution of cultural beliefs to social groups. ${ }^{33}$ While appreciating the richness of these cultural insights, those discussing this paper in 2010 noted the potential loss of structural perspectives in an early modern society that was still rigidly hierarchical and economically delimited. Scottish sources have long been recognised as problematic for quantitative analysis, yielding little hard data for structural analysis, but the cultural turn seems to have made cliometric investigations even less attractive to newer practitioners. ${ }^{34}$

\section{III}

Developments in British history have provided another major source of change in early modern Scottish history. The 'new British history' has arisen from a complex combination of circumstances, influenced by the cultural turn as well as empirical revisionism and contemporary constitutional politics. ${ }^{35}$ Within this, the cultural turn can be seen in a shift from structuralist core-periphery models of Anglicisation to notions of cultural influence, appropriation and agency, and in the widespread use of national identity as an analytical concept. Scholars disagree over the extent to which the new British history is a decentred British and imperial history, in which constituent nations take a more prominent role in the making of Britain and its empire; or an

31 C. A. Whatley, Scottish Society 1707-1830: Beyond Jacobitism, Towards Industrialisation (Manchester, 2000); A. M. Kilday, Women and Violent Crime in Enlightenment Scotland (Woodbridge, 2007), ch. 6.

32 S. Nenadic, 'Middle rank consumers and domestic culture in Edinburgh and Glasgow 1720-1840', Past Eं Present 145 (1994) 122-156.

33 T. Harris, 'The problem of "popular political culture", History of European Ideas 10 (1989) 43-58.

34 In 2004, Tom Devine noted the paucity of cliometrics in Scottish history. T. M. Devine, 'Scotland', in R. Floud and P. Johnson (eds), The Cambridge Economic History of Modern Britain: Vol. I, Industrialisation, 1700-1860 (Cambridge, 2004), 388-89. More recently, Philipp Robinson Rössner has published on Scottish macroeconomics, including Scottish Trade in the Wake of the Union, 1700-1760: the Rise of a Warehouse Economy (Stuttgart, 2008).

35 An influential call for a new approach to British history was made by J. G. A. Pocock, 'British History: a plea for a new subject', Lournal of Modern Historv 47 (1975) 601-621. 
inescapably Anglo-centric history, characterised by an Irish scholar as 'traditional English political history in mufti'. ${ }^{36}$ Though Scottish historians have been and remain ambivalent about the new British history, the shift in attention to the constituent parts of the British composite monarchy and empire has had a stimulating effect on accounts of early modern Scotland. ${ }^{37}$

Interest in the post-1603 'British problem' has accelerated what had been a slow reassessment of Scotland's seventeenth century. ${ }^{38}$ Multiplekingdom projects have highlighted the relative dearth of modern research on this period, especially in the Restoration and Revolution periods. This has forced British researchers to return to the archives to better understand the Scottish dimensions of British crisis periods. ${ }^{39}$ The British turn has helped to attract a new generation of Scottish historians to the Union of Crowns era, providing significant new work on Scotland's experience in the composite monarchy. ${ }^{40}$ Across this complex century, researchers are looking more closely at the archipelagic context of Scottish politics, using this to bring fresh insights to traditional topics from the Statutes of Iona to the religious conflicts of the 1690s. ${ }^{41}$ Recent studies on the making of the Union of 1707 have stressed the imperial context of the Union and included comparison with Ireland. ${ }^{42}$ All of this is helping the seventeenth century to recover from its Whig caricature as a period of darkness before the dawn of Union.

36 N. Canny, 'Writing early modern history: Ireland, Britain and the wider world', The Historical Journal 46 (2003) 723-747; J. M. Mackenzie, 'Irish, Scottish, Welsh and English worlds? A four-nation approach to the history of the British empire', History Compass 6 (2008) 1244-1263.

37 Macinnes, 'Early modern Scotland', 42; K. M. Brown, 'British history: a skeptical comment', Three Nations: A Common History? England, Scotland, Ireland and British History c.1600-1920 (Bochum, 1993) and Brown's less sceptical 'Seducing the Scottish Clio: has Scottish history anything to fear from the new British history?' in G. Burgess (ed.), The New British History: Founding a Modern State 1603-1715 (London, 1999). See also Laura Stewart's article in this volume.

38 D. Stevenson, 'Twilight before night or darkness before dawn? Interpreting seventeenth-century Scotland' in R. Mitchison (ed.), Why Scottish History Matters (Edinburgh, 1991).

39 T. Harris, Restoration: Charles II and his kingdoms 1660-1685 (London, 2005) and Revolution: the Great Crisis of the British monarchy 1685-1720 (London, 2006).

40 L. A. M. Stewart, Urban Politics and British Civil Wars: Edinburgh 1617-1653 (Leiden, 2006); Clare Jackson, Restoration Scotland, 1660-1690: Royalist Politics, Religion and Ideas (Woodbridge, 2000); G. H. Macintosh, The Scottish Parliament under Charles II, 1660-1685 (Edinburgh, 2007); G. Gardner, The Scottish Exile Community in the Netherlands 1660-1690 (East Linton, 2004); D. Patrick, 'Unconventional procedure: Scottish electoral politics after the Revolution' in K. M. Brown and A. J. Mann (eds), Parliament and Politics in Scotland, 1567-1707 (Edinburgh, 2005).

41 A. Cathcart, 'The Statutes of Iona: the archipelagic context', Journal of British Studies 49 (January 1010) 4-27; A. Raffe, 'Episcopalian polemic, the London printing press and Anglo-Scottish divergence in the 1690s', Journal of Scottish Historical Studies 26 (2006) 23-41.

42 Robertson (ed.), Union for Empire; A. I. Macinnes, Union and Empire: the Making of the United Kingdom in 1707 (Cambridge, 2007). 
New studies of Scotland in the British empire have sought to relocate agency in the Scottish periphery. In post-Union parliamentary history, Namierite accounts stressing the management of Scotland have been challenged by historians more attuned to a British context of public debate and lobbying. ${ }^{43}$ Recent work has sought to recover Scotland's role in creating, trading with and emigrating to colonial plantations before 1707; and has reassessed Scottish responses to the new imperial context after 1707. ${ }^{44}$ These studies have emphasised the ways in which the Scots tried to find advantage in an often disadvantageous constitutional context. Dominant images of forced migration or colonial victimhood have begun to give way to accounts that highlight the initiative of Scots in fashioning the empire and using imperial resources to refashion Scotland. In the Highlands, new research shows how landowners capitalised on their region's outdated but enduring martial image to access recruiting resources, modifying rural society in the process with the awarding of single-tenant farms and new crofts to returning officers and soldiers. ${ }^{45}$ Socio-economic change in the Highlands has been linked also to the participation of officers and lairds in metropolitan cultures of consumption, in which imperial goods were purchased by imperial paypackets and pensions. ${ }^{46}$ The darker side of agency can be seen in new research on Scottish participation in the imperial slave economy. This stresses the relatively greater contribution of slave labour and the slave trade to Scottish economic development in a British context. ${ }^{47}$

Central to the new British history has been the investigation of national identity. This analytical construct has proved useful to historians keen to explain how the people of Scotland retained a sense of cultural distinctiveness while becoming part of an expanding British monarchy and empire. New attempts to explain Britishness have stimulated fresh studies of Scottishness, revealing both the limits of British identity and the diversity of Scottishness. ${ }^{48}$ Despite its usefulness, however, the concept of national identity may be wearing

43 B. Harris, 'The Scots, the Westminster parliament and the British state in the eighteenth century', in J. Hoppit (ed.), Parliaments, Nations and Identities in Britain and Ireland, 1660-1850 (Manchester, 2003); B. Harris, 'Parliamentary legislation, lobbying and the press in eighteenth-century Scotland', Parliamentary History 26 (2007) 76-95.

44 D. Armitage, Ideological Origins of the British Empire (Cambridge, 2000); N. Canny, 'The origins of Empire: an introduction' in The Origins of Empire: British Overseas Enterprise to the Close of the Seventeenth Century (Oxford, 1988); T. M. Devine, Scotland's Empire 1600-1815 (London, 2003); Macinnes, Union and Empire.

45 A. Mackillop, 'More Fruitful than the Soil': Army, Empire and the Scottish Highlands 1715-1815 (East Linton, 2000).

46 S. Nenadic, Lairds and Luxury: the Highland Gentry in Eighteenth-Century Scotland (Edinburgh, 2007).

47 T. M. Devine, 'Did slavery make Scotia great?', Britain and the World 4 (2011) 40-64.

48 L. Colley, Britons (New Haven and London, 1992); C. Kidd, 'Protestantism, constitutionalism and British identity under the later Stuarts' and Keith M. Brown, 'Scottish identity in the seventeenth century', in B. Bradshaw and P. Roberts (eds), British Consciousness and Identity: the Making of Britain 1533-1707 (Cambridge, 1998); 
out after several decades of heavy application. One Scottish historian has questioned how far a late modern psychological model of identity can be applied to early modern societies. This query suggests that the prevailing focus on identity may tell us more about concerns in the present than conditions in the past. ${ }^{49}$

IV

Work on historical Scottishness highlights the continuing strength of a national approach to Scottish history at a time when the historical community is going global. In the burgeoning field of global history, historians look beyond traditional state boundaries. Some have explored political, economic or environmental change at supranational levels, while others have written micro-historical accounts of individuals or commodities on a global scale. ${ }^{50}$ Some consider globalisation as a human or technological phenomenon and ask how far the present time is witnessing new levels of cross-continental integration. ${ }^{51}$ Thorough-going globalists question the relevance of the nation-state as a framework for the writing of history. A recent call for 'historical cosmopolitanism' demanded 'an unthinking not only of national identity, but also of nationalist historiography' ${ }^{52}$ In contrast, since 1999, parliamentary devolution in Scotland has encouraged the publication and teaching of Scotland's national history. ${ }^{53}$

The conjunction of interest in Scottish and global history has led some scholars to adopt 'global' labels for their historical work. The traditional field of emigration studies, rejuvenated in recent years by scholars adopting network approaches from the social sciences, is now being rebranded as 'global'. ${ }^{54}$ A recent book speaks of the movement

48 (Continued) R. J. Finlay, 'Caledonia or North Britain? Scottish identity in the eighteenth century' and M. Lynch, 'A nation born again? Scottish identity in the sixteenth and seventeenth centuries' in D. Broun, R. J. Finlay and M. Lynch (eds), Image and Identity: the Making and Remaking of Scotland through the Ages (Edinburgh, 1998); C. Kidd, British Identities Before Nationalism: Ethnicity and Nationhood in the Atlantic World 1600-1800 (Cambridge, 1999).

49 C. Kidd, 'Identity before identities: ethnicity, nationalism and the historian' in J. Rudolph (ed.), History and Nation (Lewisburg, 2006).

50 For a recent review of the field, see R. Grew, 'Expanding worlds of world history', Journal of Modern History 78 (2006) 878-898.

51 M. Lang, 'Globalisation and its history', Journal of Modern History 78 (2006) 899-931.

52 D. Porter, 'Sinicizing early modernity: the imperatives of historical cosmopolitanism', Eighteenth-Century Studies 43 (2010), 299.

53 R. J. Finlay, 'New Britain, new Scotland, new history? The impact of devolution on the development of Scottish historiography', Journal of Contemporary History 36 (2001) 383-393. The teaching of Scottish history has been made compulsory at Higher level. Five topics from medieval to modern are offered in 2011 (Learning and Teaching Scotland, http://www.ltscotland.org.uk/higherscottishhistory/index.asp, accessed 23 Sept. 2011).

54 For a network approach, see S. Murdoch, Network North: Scottish Kin, Commercial and Covert Associations in Northern Europe, 1603-1746 (Leiden, 2006). 
of a global clan, while a new Centre for Diaspora Studies has received Scottish government funding to research a diasporic 'global family'. ${ }^{55}$

More fundamentally, the notion of 'multiple modernities' in global history offers a fresh way of conceptualising Scottish history within a broad international context. In contrast to older approaches that identify modernity as arising in a few privileged national contexts, particularly that of England, global history recognises multiple paths to modernity, each arising in local contexts tempered by transnational interactions. ${ }^{56}$ This approach is reinforced by a parallel shift within English historiography away from Whig exceptionalism. ${ }^{57}$ The idea of multiple modernities supports the trend noted in 1994 towards the placing of Scottish history in wider European contexts. It also invites a re-engagement with England as a historical comparator. One historian has noted the danger that the 'Scotland in Europe tactic' can be adopted 'to avoid dealing with England. ${ }^{58}$ The notion of multiple modernities allows scholars to bring England back into an analytical framework that highlights interactions as well as similarities and differences.

This brief review of early modern Scottish history suggests that the field has maintained the dynamism observed in 1994. Since the 1960s, the Scottish history has developed in maturity and sophistication, demonstrated by practitioners' continuing engagement with contemporary and disciplinary concerns. This paper does not claim that the field has innovated in a world-leading way; rather it has tended to adopt intellectual trends cautiously. As the database projects suggest, scholars have remained focused on the hard graft of empirical history. Yet, where appropriate, Scottish historians have drawn insights from cultural, British and global turns to reinvigorate traditional early modern topics. Despite globalising currents, interest in the national history of Scotland remains strong. Taken together, recent developments promise a national history that focuses on indigenous dynamics but avoids parochialism by linking these to wider contexts and approaches.

55 A. McCarthy (ed.), A Global Clan: Scottish Migrant Networks and Identities since the Eighteenth Century (London, 2006); Scottish Centre for Diaspora Studies, University of Edinburgh, http://www.shc.ed.ac.uk/centres/scdt/index.htm (accessed 29 June 2011); 'The global family of Scots', 18 January 2011, University of Edinburgh News and Events, http://www.ed.ac.uk/news/all-news/diaspora-050111 (accessed 29 June 2011). B. Wittrock, 'Early modernities: varieties and transitions', Daedalus 127 (1998) 19-40.

57 P. Lake and S. Pincus, 'Rethinking the public sphere in early modern England' in P. Lake and S. Pincus (eds), The Politics of the Public Sphere in Early Modern England (Manchester, 2007), 16-17.

58 Brown, 'Seducing the Scottish Clio', 243. 